\title{
Oceanography
}

CITATION

Lamborg, C., K. Bowman, C. Hammerschmidt, C. Gilmour, K. Munson, N. Selin, and

C.-M. Tseng. 2014. Mercury in the anthropocene ocean. Oceanography 27(1):76-87, http://dx.doi.org/10.5670/oceanog.2014.11.

DOI

http://dx.doi.org/10.5670/oceanog.2014.11

COPYRIGHT

This article has been published in Oceanography, Volume 27, Number 1, a quarterly journal of The Oceanography Society. Copyright 2014 by The Oceanography Society. All rights reserved.

USAGE

Permission is granted to copy this article for use in teaching and research. Republication, systematic reproduction, or collective redistribution of any portion of this article by photocopy machine, reposting, or other means is permitted only with the approval of The Oceanography Society. Send all correspondence to: info@tos.org or The Oceanography Society, PO Box 1931, Rockville, MD 20849-1931, USA. 


\section{MERCURY in the Anthropocene Ocean}

BY CARL LAMBORG, KATLIN BOWMAN, CHAD HAMMERSCHMIDT, CINDY GILMOUR, KATHLEEN MUNSON, NOELLE SELIN, AND CHUN-MAO TSENG

ABSTRACT. The toxic metal mercury is present only at trace levels in the ocean, but it accumulates in fish at concentrations high enough to pose a threat to human and environmental health. Human activity has dramatically altered the global mercury cycle, resulting in loadings to the ocean that have increased by at least a factor of three from pre-anthropogenic levels. Loadings are likely to continue to increase as a result of higher atmospheric emissions and other factors related to global environmental change. The impact that these loadings will have on the production of methylated mercury (the form that accumulates in fish) is unclear. In this article, we summarize the biogeochemistry of mercury in the ocean and use this information to examine past impacts that human activity has had on the cycling of this toxic metal. We also highlight ways in which the mercury cycle may continue to be affected and its potential impact on mercury in fish.

\section{INTRODUCTION}

Mercury is a notoriously toxic trace metal that has received global attention since the poisoning of thousands of people in southern Japan (Minamata and Niigata) in the mid-1950s. Ingestion of fish laden with monomethylmercury $\left(\mathrm{CH}_{3} \mathrm{Hg}^{+}\right)$caused those tragic circumstances and inspired researchers worldwide to examine mercury toxicity to humans and wildlife, measure concentrations in terrestrial and aquatic biota, and understand the biogeochemical cycling of the element's multiple forms.

Mercury (Hg) would be of little toxicological concern if it were not for its microbial and abiotic
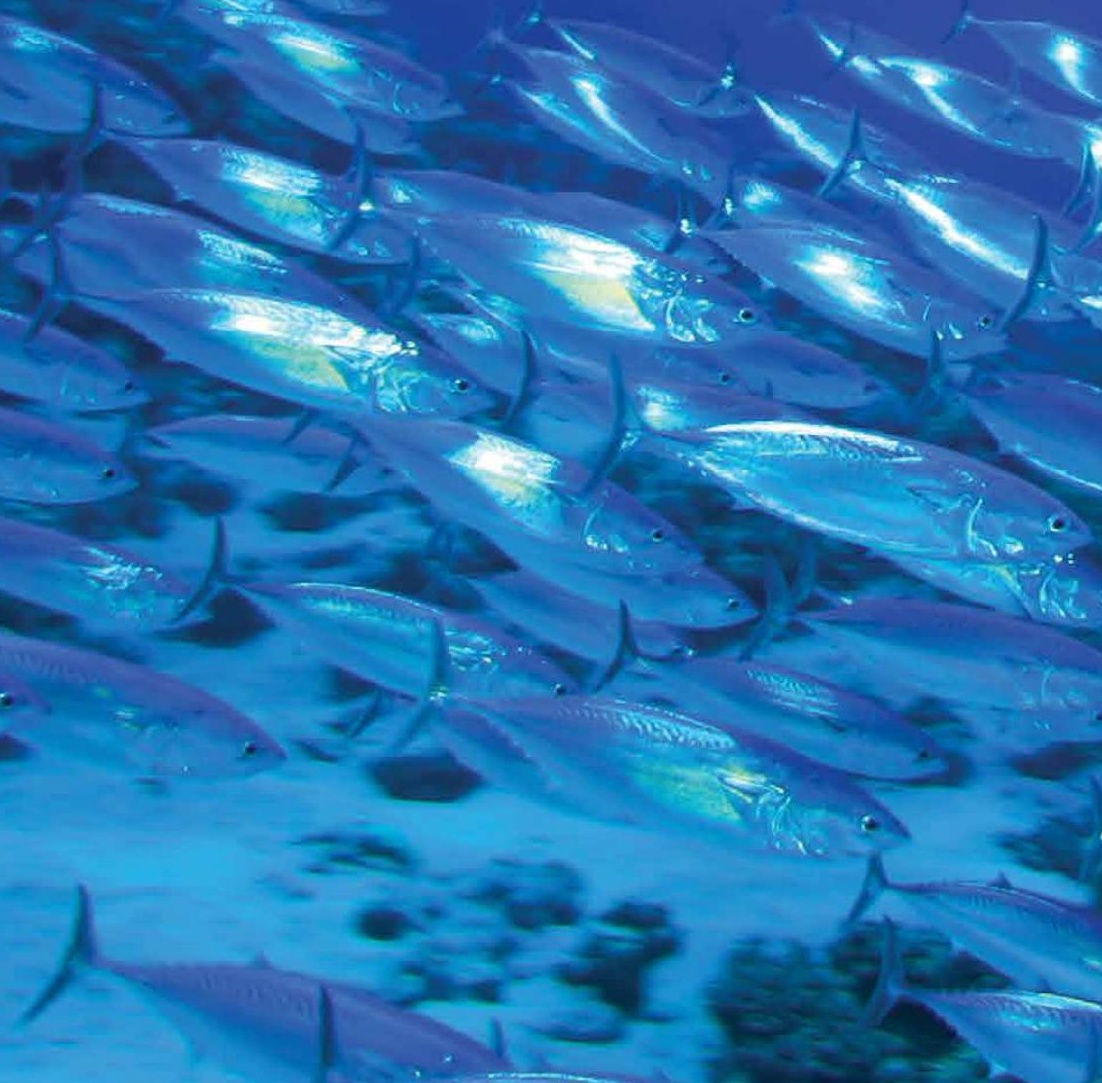
Although distributions of total mercury are important to establish, the story of mercury cycling in the ocean is fundamentally connected to its proclivity to change chemical and physical forms. Natural and anthropogenic sources emit elemental $\mathrm{Hg}$ (as well as a lesser amount of gaseous $\mathrm{Hg}(\mathrm{II})$ ). Direct atmospheric deposition is presumed to be the principal source of $\mathrm{Hg}$ (II) (mercury is oxidized to $\mathrm{Hg}(\mathrm{II})$ in the atmosphere) to most of the ocean (e.g., Driscoll et al., 2013), although rivers and groundwater can be more important in nearshore systems and the confined Arctic Ocean. This

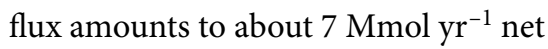
(Amos et al., 2013). Once in the marine environment, $\mathrm{Hg}(\mathrm{II})$ has a complex biogeochemistry, resulting in one of three fates (Figure 1): (1) reduction to $\mathrm{Hg}^{0}$ and evasion to the atmosphere, (2) methylation to either $\mathrm{CH}_{3} \mathrm{Hg}^{+}$or $\left(\mathrm{CH}_{3}\right)_{2} \mathrm{Hg}$, and (3) scavenging from the water column.

\section{Reduction}

Net reduction of $\mathrm{Hg}$ (II) to $\mathrm{Hg}^{0}$ proceeds strongly enough that $\mathrm{Hg}^{0}$ is often supersaturated in seawater with respect

Table 1. Summary of $\mathrm{Hg}$ species in the ocean.

\begin{tabular}{ccl} 
Species & $\begin{array}{c}\text { Typical Concentration/ } \\
\text { Percent of Total }\end{array}$ & Note \\
\hline Total Hg & $<0.1-10 \mathrm{pM}$ & \\
\hline $\mathrm{Hg}^{2+}$ & $50-100 \%$ & Generally dominant form \\
\hline $\mathrm{Hg}^{0}$ & $<5-50 \%$ & Majority in atmosphere, dissolved gas in ocean \\
\hline $\mathrm{CH}_{3} \mathrm{Hg}^{+}$ & $<20 \%$ & Species that bioaccumulates in food webs \\
\hline$\left(\mathrm{CH}_{3}\right)_{2} \mathrm{Hg}$ & $<20 \%$ & Dissolved gas, origin unknown \\
\hline
\end{tabular}

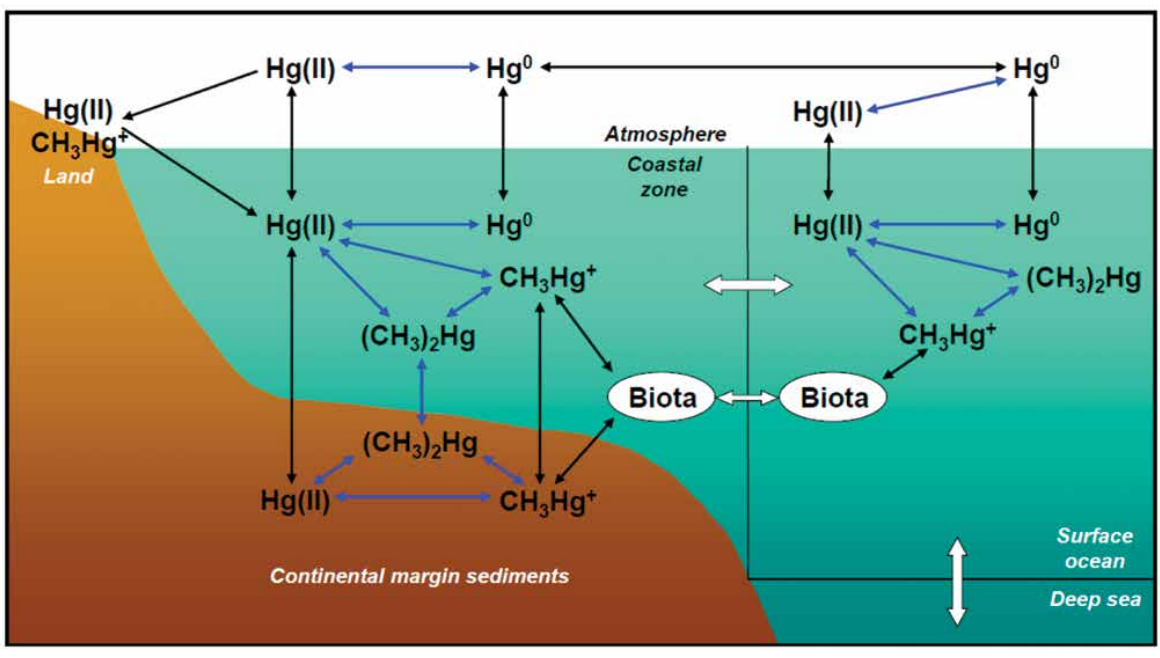

Figure 1. Conceptual model of mercury biogeochemical cycling in the ocean. Gaseous elemental mercury $\left(\mathrm{Hg}^{0}\right)$ is oxidized in the atmosphere to complexes of divalent mercury $\mathrm{Hg}(\mathrm{II})$ and deposited to land and the surface ocean. $\mathrm{Hg}(\mathrm{II})$ can be either reduced to $\mathrm{Hg}^{0}$ or methylated to form monomethylmercury $\left(\mathrm{CH}_{3} \mathrm{Hg}^{+}\right)$and dimethylmercury $\left(\left(\mathrm{CH}_{3}\right)_{2} \mathrm{Hg}\right)$. Blue arrows highlight biogeochemical transformations of mercury. Black arrows denote fluxes among the atmosphere, water, sediments, and biota. All of the mercury species can be transported hydrologically between the coastal zone, surface ocean, and deep sea, with bioaccumulative $\mathrm{CH}_{3} \mathrm{Hg}^{+}$also transported by bioadvection (white arrows; Fitzgerald et al., 2007)

to the atmosphere (Mason et al., 2012). Subsequent evasion of $\mathrm{Hg}^{0}$ to the atmosphere is half of the air-sea cycling loop and is a unique aspect of the biogeochemistry of this metal. The reduction and evasion process is a major component of the marine $\mathrm{Hg}$ cycle, with evasion fluxes removing $50-80 \%$ of gross loadings from the atmosphere. Mercury reduction in seawater is thought to occur rapidly and to include both abiotic (photochemical) reactions as well as reduction by biota. Most mercury reduction in productive coastal waters is likely accomplished by a biological mechanism that is driven by any one of several mercury-reducing bacteria. In contrast, photochemical reduction is more likely the dominant pathway in the open ocean, where light penetration is deeper and biological productivity less.

\section{Methylation and Demethylation Sediments}

External sources of the methylated forms of mercury are too low to explain their concentrations and fluxes in the ocean (e.g., Fitzgerald et al., 2007), suggesting that the primary source is internal production in sediments or the water column.

In nearshore environments and likely for continental shelves, in situ sediment production accounts for most of the $\mathrm{CH}_{3} \mathrm{Hg}^{+}$present. Other significant sources of $\mathrm{CH}_{3} \mathrm{Hg}^{+}$to nearshore systems include tidal marshes, wastewater treatment facilities, submarine groundwater discharge, and mangroves that have exceptionally high rates of mercury methylation (e.g., Driscoll et al., 2013). Principal losses of $\mathrm{CH}_{3} \mathrm{Hg}^{+}$from these waters include sedimentation, photochemical decomposition, harvesting of seafood, and export to the wider ocean.

In a recent breakthrough, Parks et al. 


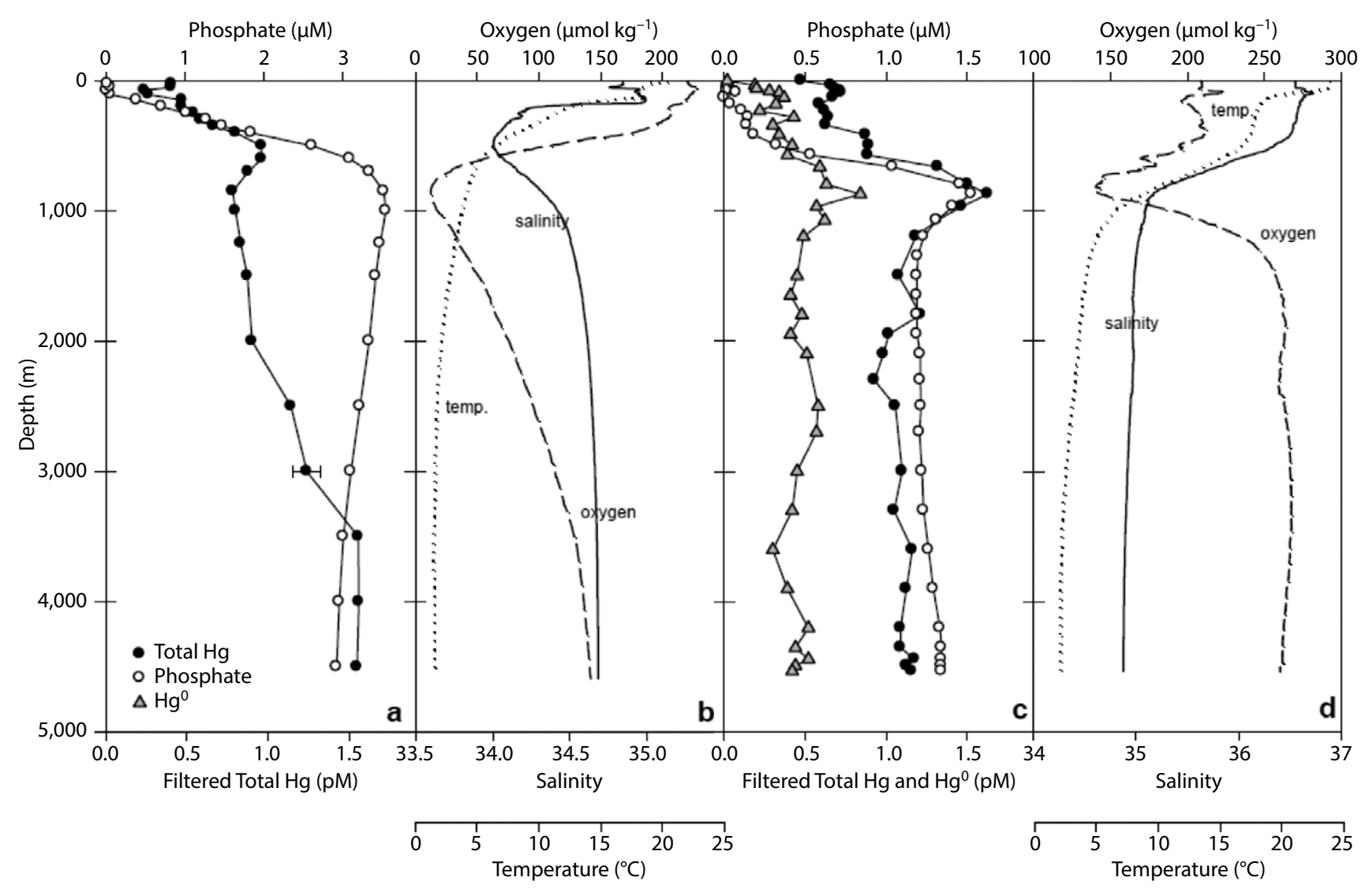

Figure 2. Vertical profiles of filtered total mercury, nutrients, and physicochemical parameters that illustrate different vertical mercury distributions in the ocean. ( $\mathrm{a}$ and $\mathrm{b}$ ) SAFe (Sampling and Analysis of Fe) program site in the North Pacific Ocean (Hammerschmidt and Bowman, 2012). (c and d) Station $10\left(31.8^{\circ} \mathrm{N}, 64.2^{\circ} \mathrm{W}\right)$ in the western North Atlantic Ocean sampled during the recent US GEOTRACES zonal section (recent work of author Bowman).

(2013) identified two genes $(h g c A$ and $h g c B$ ) that are responsible for mercury methylation in some cultured anaerobic bacteria. These genes have also been found to occur in other organisms that were not yet known to be mercury methylators and in a more diverse group of anaerobic bacteria than previously observed (Gilmour et al., 2011; Parks et al., 2013). This finding reveals that the effect of microbial population structure in methylation is still poorly understood beyond the presence/absence of the general classes of microbes that contribute to methylation. Moreover, the microbial mechanism of mercury methylation is unknown, although it is thought to be an intracellular process. Examination of the genes in greater detail should reveal much about the biochemistry of mercury methylation and should improve our understanding of its occurrence in the environment. Sources in Long Island Sound (Figure 3 ) are greater than sinks, requiring invocation of an "unknown" sink for the majority (56\%) of $\mathrm{CH}_{3} \mathrm{Hg}^{+}$ occurring there.

The genetic basis of Hg methylation notwithstanding, net production of $\mathrm{CH}_{3} \mathrm{Hg}^{+}$in coastal sediments appears to be influenced more by $\mathrm{Hg}$ (II) bioavailability than by the activity of methylating microbes. Supply of electron acceptors

Carl Lamborg (clamborg@whoi.edu) is Associate Scientist, Department of Marine Chemistry and Geochemistry, Woods Hole Oceanographic Institution (WHOI), Woods Hole, MA, USA. Katlin Bowman is a graduate student in the Department of Earth and Environmental Sciences, Wright State University, Dayton, OH, USA. Chad Hammerschmidt is Associate Professor, Department of Earth and Environmental Sciences, Wright State University, Dayton, OH, USA. Cindy Gilmour is Senior Scientist, Smithsonian Environmental Research Center, Edgewater, MD, USA. Kathleen Munson is a Joint Program student, Department of Marine Chemistry and Geochemistry, WHOI, Woods Hole, MA, USA. Noelle Selin is Assistant Professor, Engineering Systems Division and Department of Earth, Atmospheric and Planetary Sciences, Massachusetts Institute of Technology, Cambridge, MA, USA. Chun-Mao Tseng is Associate Professor, Institute of Oceanography, National Taiwan University, Taiwan. 


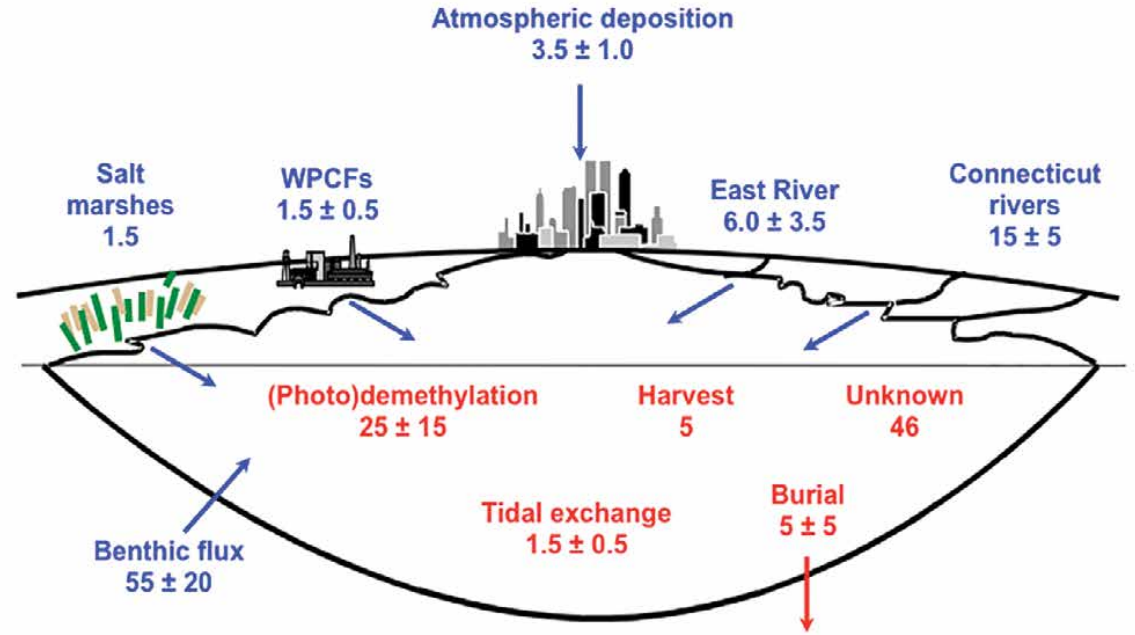

Figure 3. Mass balance $\left(\mathrm{mol} \mathrm{yr}^{-1}\right)$ for monomethylmercury in Long Island Sound, a large coastal embayment in the northeastern United States. Sources are shown in blue, sinks in red. WPCF $=$ Water Pollution Control Facility. Adapted from Balcom et al. (2004)

(e.g., $\mathrm{SO}_{4}{ }^{2-}$ or $\mathrm{Fe}(\mathrm{III})$ ) as well as labile organic matter appear to be sufficient to fuel organisms' mercury methylation even in the sandiest of marine deposits. Accordingly, geochemical factors that influence sediment-water partitioning and the chemical speciation of $\mathrm{Hg}(\mathrm{II})$ substrate greatly affect benthic production of $\mathrm{CH}_{3} \mathrm{Hg}^{+}$. Maximum rates of $\mathrm{CH}_{3} \mathrm{Hg}^{+}$production are observed in coastal sediments that have relatively low levels of both solid-phase organic matter and sulfide, which favors partitioning of $\mathrm{Hg}$ (II) species into pore water and therefore uptake by microbes (Fitzgerald et al., 2007). In contrast, $\mathrm{CH}_{3} \mathrm{Hg}^{+}$production can be inhibited in sediments with enhanced levels of either organic matter (greater particle binding) or sulfide, which shifts speciation of dissolved $\mathrm{Hg}-\mathrm{S}$ species to ionically charged complexes that are less bioavailable (e.g., Benoit et al., 1999). Therefore, Hg methylation is most effective at redox transition zones, where sulfate-reducing bacteria are present, but their sulfide byproduct is not so abundant as to sequester $\mathrm{Hg}$ in sediments.

Microbial demethylation also significantly influences net production of $\mathrm{CH}_{3} \mathrm{Hg}^{+}$; however, lack of knowledge about the mechanisms and rates of degradation remains a large gap in our understanding of $\mathrm{CH}_{3} \mathrm{Hg}^{+}$biogeochemistry in marine sediments. Multiple functional groups of anaerobic microorganisms have the ability to demethylate $\mathrm{CH}_{3} \mathrm{Hg}^{+}$ either by an oxidative process where $\mathrm{CO}_{2}$ and $\mathrm{Hg}(\mathrm{II})$ are the end products or by use of the organomercurial lyase protein, MerB, encoded on the mer operon (Barkay et al., 2003). However, microbial demethylation via the mer operon is likely not the dominant mechanism of $\mathrm{CH}_{3} \mathrm{Hg}^{+}$loss in anoxic sediment.

\section{Water Column}

$\mathrm{Hg}$ (II) also can be methylated to $\mathrm{CH}_{3} \mathrm{Hg}^{+}$and $\left(\mathrm{CH}_{3}\right)_{2} \mathrm{Hg}$ in the marine water column (Figure 1; the sum of the two species denoted as $\mathrm{\Sigma CH}_{3} \mathrm{Hg}$ ). The most striking feature of the vertical distribution of $\mathrm{\Sigma CH}_{3} \mathrm{Hg}$ is the ubiquitous maximum in oxygen minimum zones (OMZs), typically from $500-1,000 \mathrm{~m}$ water depth (Figure 4). Maxima of $\Sigma \mathrm{CH}_{3} \mathrm{Hg}$ in OMZs have been widely attributed to in situ methylation fueled by microbial remineralization of organic matter (e.g., Mason and Fitzgerald, 1993), the process that also is partly responsible for the oxygen minimum, in addition to a slow rate of ventilation in the thermocline. Sectional oceanographic studies have observed associations between methylated mercury species and either apparent oxygen utilization (AOU) or the rate of organic carbon remineralization (Sunderland et al., 2009), which suggests that production of methylated mercury in the marine water column is limited by methylation potential more than it is by $\mathrm{Hg}(\mathrm{II})$ availability.

Much of the previous research that describes mercury methylation under anoxic conditions may be of little use in understanding $\mathrm{CH}_{3} \mathrm{Hg}^{+}$dynamics in the open ocean. Although strains of ironand sulfate-reducing bacteria methylate mercury in anoxic sediments (Gilmour et al., 2011), neither functional group is active in the marine water column except under conditions of extreme suboxia associated with some OMZs and microenvironments in sinking particles. The prevalence of $\mathrm{CH}_{3} \mathrm{Hg}^{+}$and $\left(\mathrm{CH}_{3}\right)_{2} \mathrm{Hg}$ throughout the oxic ocean and active rates of mercury methylation in oxic surface waters (Mason et al., 2012) imply that the ability to methylate mercury is widespread among microorganisms, including aerobes.

\section{Burial}

On time scales of tens of thousands of years and more, the ultimate sink for mercury is burial in marine sediments (e.g., Fitzgerald et al., 2007; Amos et al., 2013). Unfortunately, there is not a great deal of data regarding the concentration of mercury in deep-sea sediments. As a result, we do not have well-constrained estimates for the rate at which sedimentation removes mercury from the 
ocean. We can make a first order estimate using studies that observed correlations between mercury and organic matter in sediments (e.g., Fitzgerald et al., 2007) along with estimates for the amount of organic carbon buried on continental shelves and the abyssal ocean. This approach suggests that about $1 \mathrm{Mmol} \mathrm{yr}^{-1}$ of mercury is buried in global abyssal sediments, while almost $2 \mathrm{Mmol} \mathrm{yr}^{-1}$ are buried on continental shelves. This mercury eventually makes its way back into the global cycle through subduction of marine sediments at active margins, reappearing as mercury volatilized from volcanoes and associated deposits. However, it is clear that more $\mathrm{Hg}$ is going into the ocean each year

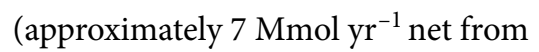
atmosphere and rivers; e.g., Amos et al., 2013) than is leaving through burial, leading to inevitable increases.

\section{ANTHROPOGENIC LOAD}

\section{TIMING AND MAGNITUDE}

As mentioned earlier, human activity has significantly increased the amount of mercury present in biologically active reservoirs at a variety of scales. At present, there is conflicting information regarding the amount of pollution mercury that has been released, the timing of the releases, and fate of that material. As a result of complex biogeochemistry and resulting mobility, it is clear that, once released, pollution mercury remains active and contributes to the amount found in active environmental reservoirs (e.g., Amos et al., 2013). Thus, there are reservoirs of "legacy" mercury in the ocean, atmosphere, and soils that must be tracked to adequately assess pollution impacts and that will necessarily result in lags between corrective actions (such as reducing emissions) and subsequent declines in the environment. A critical area of research in environmental mercury biogeochemistry is assessment of the scope of mercury perturbations in time and space and inclusion of such information in models that will allow predictions to be made.

Our recent research as part of the GEOTRACES program (Anderson et al., 2014, in this issue; http://www. geotraces.org) allows us to estimate the amount of anthropogenic mercury in the ocean from direct oceanographic measurements (Box 1). We compared the concentration of total mercury to that of remineralized phosphate in deep and intermediate waters from around the world, with an emphasis on the North and South Atlantic. Interestingly, mercury concentrations correlate well with remineralized phosphate in all deep waters except the North Atlantic,

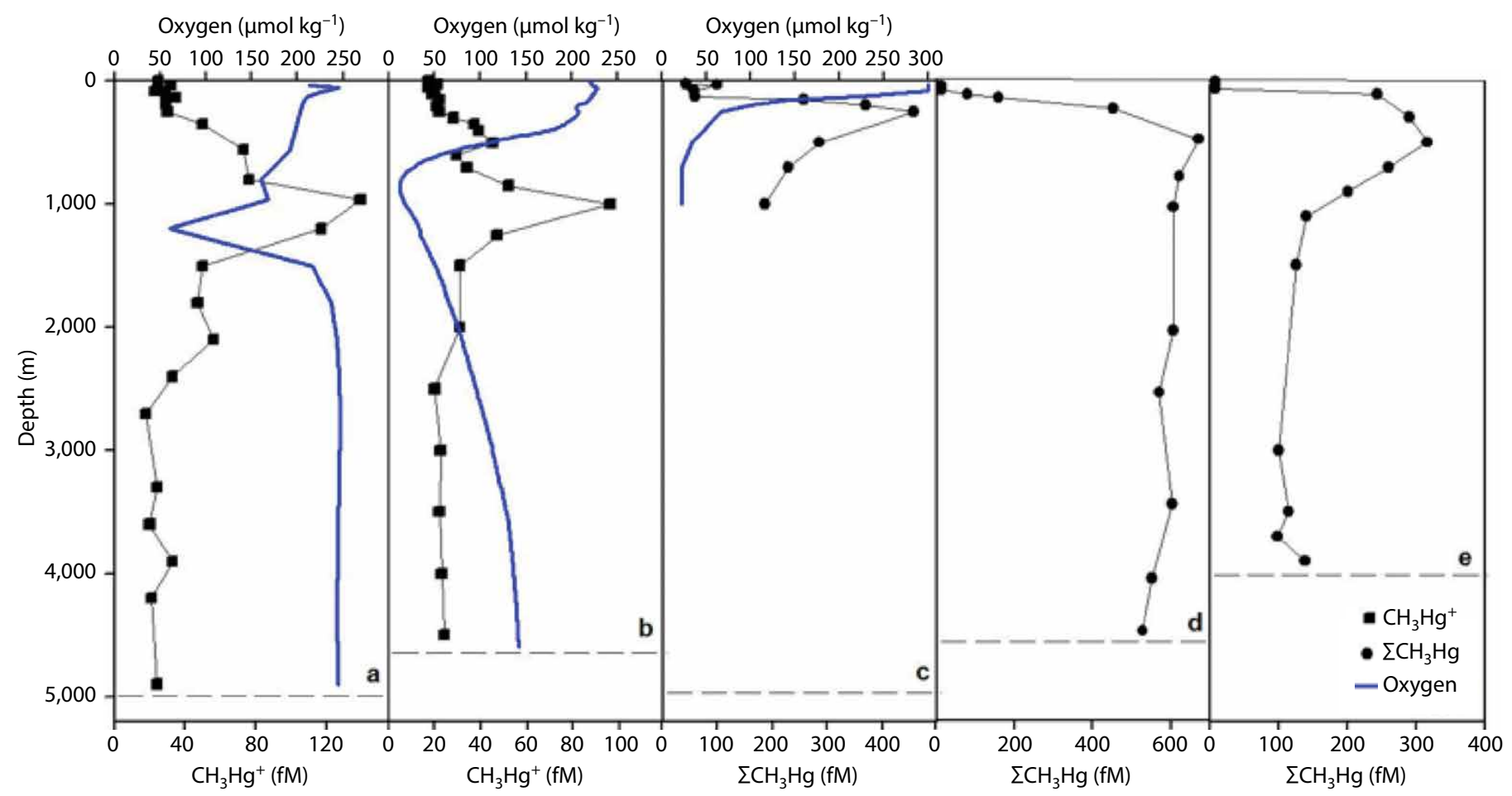

Figure 4. Representative profiles of monomethylmercury $\left(\mathrm{CH}_{3} \mathrm{Hg}^{+}\right)$and total methylated mercury $\left(\Sigma \mathrm{CH}_{3} \mathrm{Hg}\right)$ in seawater, illustrating a connection to dissolved oxygen distributions. Filtered $\mathrm{CH}_{3} \mathrm{Hg}^{+}$in (a) Northeast Atlantic Ocean (recent work of author Bowman), and (b) subtropical North Pacific Ocean (Hammerschmidt and Bowman, 2012). $\Sigma \mathrm{CH}_{3} \mathrm{Hg}$ in unfiltered water of the (c) sub-Arctic North Pacific (Sunderland et al., 2009), (d) Southern Ocean (Cossa et al., 2011), and (e) Mediterranean Sea (Cossa et al., 2009). Dashed lines denote the depth of the sediment-water interface. 
As with many trace elements in the ocean, measuring ambient concentrations of mercury $(\mathrm{Hg})$ in seawater can be challenging. One of the first steps in many trace analyses is isolating the analyte from all the potentially complicating salts and pre-concentrating from large volumes to obtain a visible signal. In the case of $\mathrm{Hg}$, we are fortunate that one form, $\mathrm{Hg}^{0}$, is volatile. Thus, if all $\mathrm{Hg}$ species could be rendered into this form, it could be stripped from a seawater sample and collected using some variant of purge-and-trap techniques. Generally, this is done through oxidation of $\mathrm{Hg}$ species to $\mathrm{Hg}$ (II) first, usually using $\mathrm{Br}_{2}$ dissolved in $\mathrm{HCl}$ (or $\mathrm{BrCl}$ as it is sometimes called) and then reducing the $\mathrm{Hg}(\mathrm{II})$ to $\mathrm{Hg}^{0}$ using either $\mathrm{NaBH}_{4}$ or $\mathrm{SnCl}_{2}$. The preconcentration trapping of the purged $\mathrm{Hg}^{0}$ is usually done by exploiting the spontaneous amalgamation of elemental $\mathrm{Hg}$ and Au to one another, a procedure pioneered by William F. Fitzgerald and students at the University of Connecticut in the 1970s, 1980s, and 1990s. This key component of the method, which has been subsequently refined, allows pico- and femtomolar concentrations of mercury to be isolated and determined from seawater. The form of gold (Au) can vary, but it is usually quartz sand with a thin coating of $\mathrm{Au}^{0}$. In a bit of chemical irony, this method represents the converse of the way in which mercury has long been used in gold mining, where mercury is added to a sediment/rock/water slurry, the mixture is agitated, and the gold is allowed to amalgamate to the mercury. Later, the dense mercury is recovered from the slurry through settling and then boiled off to reveal the precious gold. Thus, today, $\mathrm{Hg}$ analysts use essentially the same technology that resulted in contamination in the past to study the impact of that contamination. The organomercury compounds are determined in a similar process, by derivitization rather than reduction, purge, and trap onto organic-trapping Tenax instead of gold, and separation by gas chromatography prior to analysis to isolate the methylated forms from $\mathrm{Hg}^{0}$ and $\mathrm{Hg}(\mathrm{II})$. As part of the US GEOTRACES program, all of these analyses are performed at sea in a self-contained $\mathrm{Hg}$ lab (see figure).

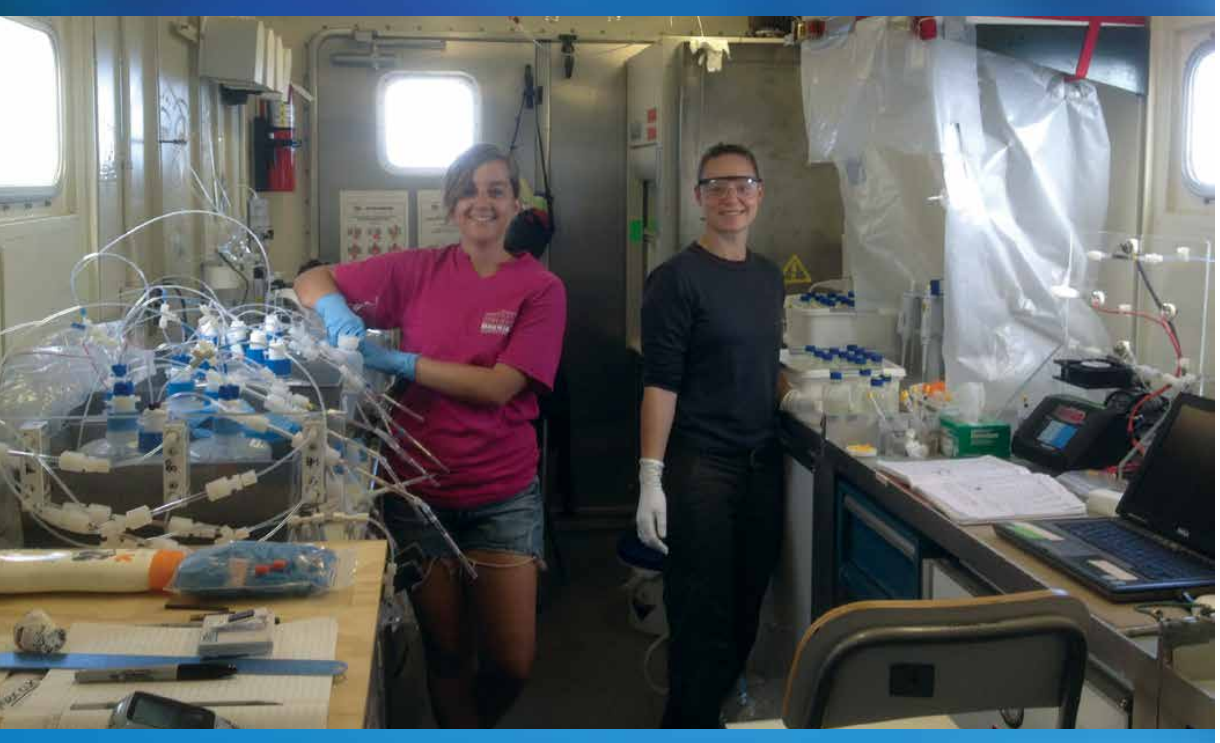

A view inside the mercury lab van during the US GEOTRACES eastern tropical South Pacific cruise. Katlin Bowman (left) of Wright State University and Gretchen Swarr of Woods Hole Oceanographic Institution are hard at work. indicating that mercury under nonpollution conditions behaves much like a macronutrient: it increases in concentration as it is swept along the oceanic conveyor belt through the deep Atlantic, into the deep Southern Ocean, then into the deep Indian, and eventually the deep North Pacific. In contrast, mercury-to-remineralized phosphate ratios were greatly increased in North Atlantic Deep Water and some intermediate waters, indicating anthropogenic impact. The excess anthropogenic mercury accounts for about 300 Mmoles present in the ocean today, denoting increased concentrations in the surface ocean, permanent thermocline, and deep ocean regions of about $250 \%, 160 \%$, and $10 \%$, respectively.

Our estimate of the amount of anthropogenic mercury in the ocean is consistent with the amounts predicted by previous modeling efforts, in particular, that of Sunderland and Mason (2007). Their model is one of the few to explicitly include deepwater formation when considering the fate of mercury in the ocean. They found about $49 \%$ of total anthropogenic mercury resides below 1,500 m water depth, similar to our measurements. The model highlights the importance that deepwater formation plays in the fate of anthropogenic $\mathrm{Hg}$ in the short term (century to millennium time scale); if this process were not to occur, our results suggest that almost twice as much mercury would currently reside in the surface ocean. This dynamic also has something to tell us about the future of $\mathrm{Hg}$ in the ocean. It is predicted that in the next 50 years, as much $\mathrm{Hg}$ could be released from industry as has been released in the previous 150 (Streets et al., 2009). However, of the future $\mathrm{Hg}$ added to the ocean, a larger proportion will be found in shallower water and 
will therefore be potentially available for inclusion in the marine food web. In short, not only will $\mathrm{Hg}$ concentrations in the surface ocean continue to rise along with emissions, but that rise could be at a faster rate than emissions. Because the residence time of mercury in the mixed layer is only $0.5-1$ years, if we reduce atmospheric mercury inputs to the open ocean, there should be a proportional and immediate reduction of mercury concentrations in pelagic food webs.

Historical archives provide compelling evidence of mercury concentration increases in biologically important reservoirs in the ocean. They suggest $200-500 \%$ increases of $\mathrm{CH}_{3} \mathrm{Hg}^{+}$concentration in the ocean since industrialization. Such an increase of $\mathrm{CH}_{3} \mathrm{Hg}^{+}$ in seabirds is consistent with the GEOTRACES-based estimate of $\mathrm{Hg}$ (II) increases (e.g., Mason et al., 2012). It is possible that changes in the recent past and in some locations may very well be different from global averages. Thus, a conservative description of the state-ofthe-science is that many studies support the hypothesis that increased emissions of $\mathrm{Hg}$ result in higher $\mathrm{Hg}$ concentrations in fish in the ocean, but there is still much we do not know.

The response of $\mathrm{CH}_{3} \mathrm{Hg}^{+}$production in sediments on the continental margin is likely to influence future changes in $\mathrm{Hg}$ (II) loadings from either the atmosphere or rivers because surface sediments in nearshore and remote continental shelf regions have accumulated massive reservoirs of $\mathrm{Hg}$ (II) since the beginning of human $\mathrm{Hg}$ loadings. Benthic infauna mix this pool of "legacy" mercury throughout the upper $10+\mathrm{cm}$ of surface sediment. Its burial and removal from active zones of methylation (upper few centimeters) will occur only after centimeters of new sediment are added, which will take decades to centuries in most systems. Future changes in $\mathrm{CH}_{3} \mathrm{Hg}^{+}$production and bioaccumulation in coastal ecosystems are most likely to result from alterations of water quality that is hypothesized to influence $\mathrm{Hg}(\mathrm{II})$ bioavailability, benthic competing impacts on the mercury cycle. Thus, as with many aspects of global change science, the impact on the mercury cycle is very uncertain, which complicates the job of planning for or mitigating the impact of future mercury loadings to the ocean.

\section{SC ...NOT ONLY WILL Hg CONCENTRATIONS IN THE SURFACE OCEAN CONTINUE TO RISE ALONG WITH EMISSIONS, BUT THAT RISE COULD BE AT A FASTER RATE THAN EMISSIONS.}

$\mathrm{CH}_{3} \mathrm{Hg}^{+}$flux, and the size and composition of the biological pool into which $\mathrm{CH}_{3} \mathrm{Hg}^{+}$is accumulated, but these effects are poorly constrained (Amos et al., 2013; Driscoll et al., 2013).

\section{GLOBAL CHANGE IMPACT ON THE MERCURY CYCLE}

In addition to the possibility of increased mercury loadings to the ocean in the future, other changes in the marine mercury cycle could occur as a result of changes in climate, ocean physics, and productivity, as well as land use and terrestrial mercury cycling. Several studies have contemplated the potential impact that global change might have on the mercury cycle (e.g., AMAP, 2011; Amos et al., 2013; Krabbenhoft and Sunderland, 2013; UNEP, 2013). However, our current understanding of the dependencies of various aspects of mercury biogeochemistry on these various forcings is too limited to make firm predictions. For example, Table 2 shows a few of the forcings that have been considered, some of which display

\section{REGIONAL IMPACT CASE STUDIES}

The future of human impacts on the ocean regarding $\mathrm{Hg}$ can already be seen in some locations. Below, we highlight two case studies: one in the South China Sea, which is directly downwind and downriver from the region of largest current anthropogenic $\mathrm{Hg}$ emissions, and the other in the Arctic, where a changing climate and unusual atmospheric dynamics combine to threaten people and food webs.

\section{South China Sea}

The South China Sea (SCS) receives riverine and atmospheric loadings of $\mathrm{Hg}$ from China and surrounding areas, which are among the highest emitters of $\mathrm{Hg}$ at present. As a result, the concentrations of $\mathrm{Hg}$ found in the SCS are unusually high for a large marginal sea, ranging from 3-10 pM (Fu et al., 2010; Tseng et al., 2012). In contrast, the Mediterranean Sea, which is nearly the same size as the SCS, exhibits $\mathrm{Hg}$ concentrations that are about five times less 
and receives a total areal $\mathrm{Hg}$ load that is less than half that of the SCS. Indeed, the SCS is closer in areal loading to urbanized embayments like Long Island Sound than the Mediterranean (Table 3). So much $\mathrm{Hg}$ is in the air over the SCS that in winter, when winds are from the northwest, $\mathrm{Hg}^{0}$ invades the sea in a situation rarely observed anywhere else (evasion is the norm; Tseng et al., 2013). At most times of the year, the evasional flux of $\mathrm{Hg}$ from the SCS is virtually the same as that from the Mediterranean and other ocean regions, implying that evasion may not be proportional to total
$\mathrm{Hg}$, as is frequently assumed (e.g., Amos et al., 2013). If this is the case, then progressively larger percentages of $\mathrm{Hg}$ loadings to the wider ocean can be expected to remain there than current models predict. If the future of most ocean regions is anything like the SCS, the impact of human emissions may be more serious than we currently appreciate.

\section{The Arctic}

There are two reasons that the Arctic is of concern with respect to global mercury change. First, during springtime, so-called Arctic Mercury Depletion
Events regularly occur, where a large fraction of lower tropospheric $\mathrm{Hg}$ is oxidized and deposited to snow and ice. The chemistry behind this process is not perfectly understood, but likely involves reactive halogen species that are generated during polar sunrise. The result is a large deposition of $\mathrm{Hg}$ to the surface in a short period of time that, were it to remain, could threaten Arctic ecosystems. However, chemical activity that occurs in snow and ice results in the reduction and evasion of a substantial fraction of this deposited $\mathrm{Hg}$, lowering the net effect of Depletion Events.

Table 2. Potential responses of the marine mercury cycle to various global change forcings. Suggestions are from Fitzgerald et al. (2007), AMAP (2011), Driscoll et al. (2013), Amos et al. (2013), Dijkstra et al. (2013), Krabbenhoft and Sunderland (2013), Selin (2013), and UNEP (2013).

\begin{tabular}{|c|c|c|}
\hline Global Change Forcing & Result & Impact on Ocean Hg \\
\hline \multicolumn{3}{|l|}{ ATMOSPHERE-RELATED } \\
\hline \multirow{4}{*}{ Warming atmosphere } & $\begin{array}{l}\text { Decrease in } \mathrm{Br} \text { oxidation of } \mathrm{Hg}^{0} \text { in } \\
\text { atmosphere, longer atmosphere } \\
\text { residence time }\end{array}$ & Decreased evasion as atmospheric concentration increases \\
\hline & $\begin{array}{l}\text { Increased convection, shorter } \\
\text { atmosphere residence time. }\end{array}$ & Increased evasion as atmospheric concentration decreases \\
\hline & Slower circulation, slower wind speeds & Decreased evasion \\
\hline & Increased precipitation & Increased evasion as atmospheric concentration decreases \\
\hline $\begin{array}{l}\text { Increased oxidative } \\
\text { capacity (e.g., ozone) }\end{array}$ & $\begin{array}{l}\text { Decrease in } \mathrm{Br} \text { oxidation of } \mathrm{Hg}^{0} \text { in } \\
\text { atmosphere, longer residence time }\end{array}$ & Decreased evasion as atmospheric concentration increases \\
\hline \multicolumn{3}{|l|}{ EMISSIONS-RELATED } \\
\hline \multirow{2}{*}{ Warming soil } & Increased soil evasion rate constant & Increased loading to ocean \\
\hline & Decreased soil C storage & Increased loading to ocean \\
\hline Increased biomass burning & Increased emissions & Increased loading to ocean \\
\hline \multicolumn{3}{|l|}{ OCEAN-RELATED } \\
\hline \multirow{5}{*}{$\begin{array}{l}\text { Increased ocean } \\
\text { temperatures }\end{array}$} & Increased respiration & Increased $\mathrm{CH}_{3} \mathrm{Hg}^{+}$production \\
\hline & \multirow{2}{*}{ Stronger stratification } & Decreased $\mathrm{CH}_{3} \mathrm{Hg}^{+}$production from lower primary production \\
\hline & & Decreased surface water concentrations due to more sluggish ventilation \\
\hline & Increased fish metabolism & Increased bioaccumulation/magnification of $\mathrm{CH}_{3} \mathrm{Hg}^{+}$ \\
\hline & Expansion of oxygen minimum & $\begin{array}{l}\text { Depends on cause: if organic carbon remineralization rate does not } \\
\text { change, no effect }\end{array}$ \\
\hline Rising sea level & Short-term inundation of coastline & Short-term pulse of $\mathrm{Hg}$ and $\mathrm{CH}_{3} \mathrm{Hg}^{+}$into coastal zone \\
\hline \multirow{2}{*}{ Coastal eutrophication } & Increased phytoplankton biomass & Decreased $\mathrm{CH}_{3} \mathrm{Hg}^{+}$concentration by biodilution \\
\hline & Increased C flux to sediments & Decreased $\mathrm{CH}_{3} \mathrm{Hg}^{+}$production through thinning of suboxic zone \\
\hline
\end{tabular}


The events themselves may not be new phenomena (Drevnick et al., 2012), but with the loss of sea ice in the Arctic, the process of re-emission of $\mathrm{Hg}$ deposited by Depletion Events may decrease in the future, dramatically increasing the net load to the Arctic Ocean (assuming snow is better at reducing/evading $\mathrm{Hg}$ than the ocean).

A second cause for concern is the impact that global change is having on $\mathrm{Hg}$ loadings to the Arctic Ocean from rivers. The Arctic Ocean is a uniquely river-influenced basin, and warming appears to have resulted in a dramatic increase in riverine flow into this stretch of ocean. Much of this increased freshwater is thought to arise from the melting of permafrost that releases a substantial amount of organic carbon in the process. Mercury stored in permafrost soils is also released during this process, and modeling estimates suggest that the result could be a substantial increase in $\mathrm{Hg}$ loadings from rivers in the coming years (Fisher et al., 2012). The impact of all these forces might already be having an effect, as certain populations of
Arctic animals appear to be threatened by Hg-induced loss of fecundity (Tartu et al., 2013), and others are likely to follow (AMAP, 2011). As with global warming, the Arctic may be the "canary in the coal mine" for the impact of our past, present, and future releases of mercury to the environment.

\section{WHAT CAN BE DONE?}

The future trajectory of ocean mercury depends on socioeconomic and technological factors. Historically, dramatic increases in mercury emission associated with industrialization have increased mercury loading to the ocean. While efforts in several developed countries (including the United States and Europe) have resulted in emissions decreases there, rapidly industrializing countries are currently the main source of atmospheric mercury. Depending on how countries industrialize, and what controls are put in place, particularly in Asia, anthropogenic mercury emissions in 2050 could increase by $96 \%$, or decrease by $4 \%$, or anything in between, relative to 2006 emissions (Streets et al.,
2009). Under the highest emission scenario, net deposition to the global ocean is projected to increase by $33 \%$ (Corbitt et al., 2011).

As present-day anthropogenic sources represent only a fraction (about onethird) of the global emission of mercury to the atmosphere, quantifying the time scales of legacy emissions is critical to determining the future of ocean mercury. Importantly, mercury released now is tomorrow's legacy mercury. Global simulations show that future increases in legacy mercury substantially add to estimates of changes in atmospheric deposition under policy scenarios (Amos et al., 2013; Sunderland and Selin, 2013). Thus, controlling emissions today has a long-term benefit.

Policy actions at national, regional, and global scales have addressed mercury pollution sources. In the United States, the recent Mercury and Air Toxics Standards mandate mercury emissions reductions for the first time from power generation sources, in particular, coal-fired power plants. Globally, the Minamata Convention is a new,

Table 3. First-order total $\mathrm{Hg}$ mass balances for several embayments and marginal seas. Fluxes in $\mathrm{nmol} \mathrm{m} \mathrm{fr}^{-2} \mathrm{yr}^{-1}$. Data are from Fitzgerald et al. (2007), Rajar et al. (2007), Fu et al. (2010), and Tseng et al. (2012).

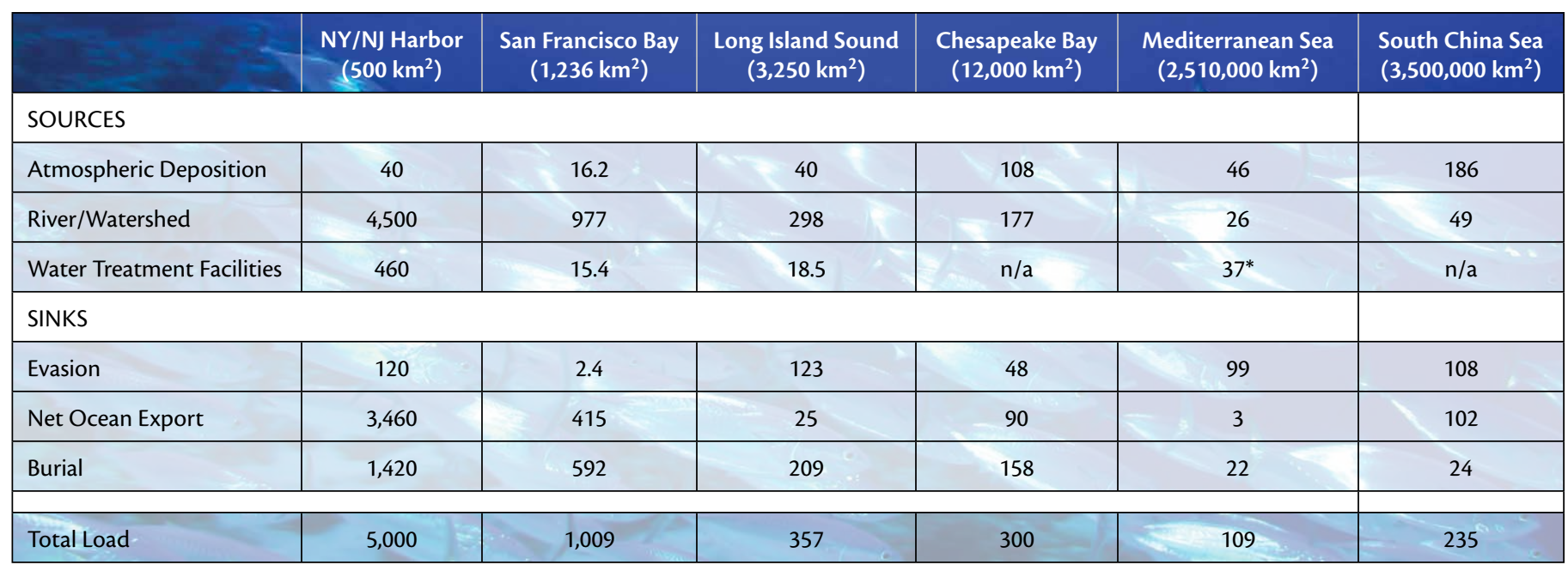

*This term includes geological and anthropogenic point sources. $\mathrm{n} / \mathrm{a}=\mathrm{not}$ available. 
legally binding international agreement designed to protect human health and the environment from anthropogenic emissions and releases of mercury. The Convention, signed in October 2013, takes a life-cycle approach, addressing mercury production, use, trade, and emissions. Provisions that could have
ASGM inventory and the quantification of how much mercury enters the global atmosphere where it might affect the open ocean and/or remain in local waterways, reducing this source will have benefits on both local and global scales. Under the Minamata Convention, parties with more than insignificant

\section{a ...THE ARCTIC MAY BE THE "CANARY IN THE COAL MINE" FOR THE IMPACT OF OUR PAST, PRESENT, AND FUTURE RELEASES OF MERCURY TO THE ENVIRONMENT.}

the largest impact on the global ocean are those on atmospheric emissions, releases to land and water, and artisanal and small-scale gold mining (ASGM). On emissions, the Convention requires the application of best available techniques and best environmental practices (BAT/BEP) for new sources, starting five years after the treaty's entry into force (which will likely be 2015 , at the earliest). The concept of BAT/BEP takes into account both technical and economic feasibility of controls. For existing sources, parties are required to choose from a variety of measures to control and, where feasible, reduce emissions, starting 10 years after entry into force.

Convention provisions on ASGM could also impact future deposition to the ocean. Though previous mercury emission inventories identified stationary combustion as the largest global atmospheric emission sector, the most recent inventory by the United Nations Environment Programme estimates that ASGM is the largest (UNEP, 2013). While there is much uncertainty in the
ASGM are required to develop a national action plan and take steps to reduce and, where feasible, eliminate the use and release of mercury in these activities.

Taken together, Minamata Convention provisions could, optimistically, result in an emissions trajectory at the low end of those projected for 2050, with implementation of basic emissions controls on a large range of sources (Sunderland and Selin, 2013). These actions would result in avoiding the large increases projected under business-as-usual, but little change from today to 2050 in the amount of mercury in the ocean. This scenario suggests that environmental improvements would require more aggressive action in the future, and that the initial importance of the Minamata Convention may be in raising awareness legally and politically about mercury as a global environmental contaminant.

Moving forward, several lessons emerge for future mercury policy. Experience with regional mercury management suggests that future policy should take into account transboundary influences, coordinate across environmental media, and better assess human and ecological impacts in regulatory analyses. With the new Minamata Convention, coordinating policies across scales-ensuring that national, regional, and international actions are consistent and reinforcing-will become more important. In addition, because mercury is a legacy pollutant, population risks could be further minimized by improved adaptive measures, such as fish advisories, before the benefits of international policy are fully realized.

\section{ACKNOWLEDGEMENTS}

We thank Elsie Sunderland, Rob Mason, Ken Johnson, and Bill Landing for helpful discussions. The US GEOTRACES research reported herein was supported by the US National Science Foundation Chemical Oceanography program. National Taiwan University also supported this work through the Drunken Moon Lake Scientific Integrated Scientific Research Platform grant, NTU\#102R3252. D

\section{REFERENCES}

AMAP (Arctic Monitoring and Assessment Programme). 2011. AMAP Assessment 2011: Mercury in the Arctic. Oslo, Norway, 193 pp. Available online at: http://www.amap. no/documents/doc/amap-assessment2011-mercury-in-the-arctic/90 (accessed December 8, 2013).

Amos, H.M., D.J. Jacob, D.G. Streets, and E.M. Sunderland. 2013. Legacy impacts of all-time anthropogenic emissions on the global mercury cycle. Global Biogeochemical Cycles 27:410-421, http://dx.doi.org/10.1002/ gbc.20040.

Anderson, R.F., E. Mawji, G.A. Cutter, C.I. Measures, and C. Jeandel. 2014. GEOTRACES: Changing the way we explore ocean chemistry. Oceanography 27(1):50-61, http://dx.doi.org/10.5670/oceanog.2014.07.

Balcom, P.H., W.F. Fitzgerald, G.M. Vandal, C.H. Lamborg, K.R. Rolfhus, C.S. Langer, and C.R. Hammerschmidt. 2004. Mercury sources and cycling in the Connecticut River and Long Island Sound. Marine Chemistry 90:53-74, http://dx.doi.org/10.1016/ j.marchem.2004.02.020. 
Barkay, T., S.M. Miller, and A.O. Summers. 2003. Bacterial mercury resistance from atoms to ecosystems. FEMS Microbiology Reviews 27:355-384, http://dx.doi.org/10.1016/ S0168-6445(03)00046-9.

Benoit, J.M., C.C. Gilmour, R.P. Mason, and A. Heyes. 1999. Sulfide controls on mercury speciation and bioavailability to methylating bacteria in sediment pore waters. Environmental Science \& Technology 33:951-957, http://dx.doi.org/10.1021/es9808200.

Corbitt, E.S., D.J. Jacob, C.D. Holmes, D.G. Streets, and E.M. Sunderland. 2011. Global sourcereceptor relationships for mercury deposition under present-day and 2050 emissions scenarios. Environmental Science \& Technology 45:10,477-10,484, http://dx.doi.org/ 10.1021/es202496y.

Cossa, D., B. Averty, and N. Pirrone. 2009. The origin of methylmercury in open Mediterranean waters. Limnology and Oceanography 54:837-844, http://dx.doi.org/ 10.4319/lo.2009.54.3.0837.

Cossa, D., L.E. Heimburger, D. Lannuzel, S.R. Rintoul, E.C.V. Butler, A.R. Bowie, B. Averty, R.J. Watson, and T. Remenyi. 2011. Mercury in the Southern Ocean. Geochimica et Cosmochimica Acta 75:4,037-4,052, http:// dx.doi.org/10.1016/j.gca.2011.05.001.

Dijkstra, J.A., K.L. Buckman, D. Ward, D.W. Evans, M. Dionne, and C.Y. Chen. 2013. Experimental and natural warming elevates mercury concentrations in estuarine fish. PLOS ONE 8(3):e58401, http://dx.doi.org/ 10.1371/journal.pone.0058401.

Drevnick, P.E., H. Yang, C.H. Lamborg, and N.L. Rose. 2012. Net atmospheric mercury deposition to Svalbard: Estimates from lacustrine sediments. Atmospheric Environment 59:509-513, http://dx.doi.org/ 10.1016/j.atmosenv.2012.05.048.

Driscoll, C.T., R.P. Mason, H.M. Chan, D.J. Jacob, and N. Pirrone. 2013. Mercury as a global pollutant: Sources, pathways, and effects. Environmental Science \& Technology 47:4,967-4,983, http://dx.doi.org/ 10.1021/es305071v.

Fisher, J.A., D.J. Jacob, A.L. Soerensen, H.M. Amos, A. Steffen, and E.M. Sunderland. 2012. Riverine source of Arctic Ocean mercury inferred from atmospheric observations. Nature Geoscience 5:499-504, http://dx.doi.org/ 10.1038/ngeo1478.

Fitzgerald, W.F., C.H. Lamborg, and C.R. Hammerschmidt. 2007. Marine biogeochemical cycling of mercury. Chemical Reviews 107:641-662, http://dx.doi.org/ $10.1021 / \mathrm{cr} 050353 \mathrm{~m}$.

Fu, X.W., X. Feng, G. Zhang, W. Xu, X. Li, H. Yao, P. Liang, J. Li, J. Sommar, R. Yin, and N. Liu. 2010. Mercury in the marine boundary layer and seawater of the South China Sea: Concentrations, sea/air flux, and implication for land outflow. Journal of Geophysical Research 115, D06303, http://dx.doi.org/ 10.1029/2009jd012958.
Gilmour, C.C., D.A. Elias, A.M. Kucken, S.D. Brown, A.V. Palumbo, C.W. Schadt, and J.D. Wall. 2011. Sulfate-reducing bacterium Desulfovibrio desulfuricans ND132 as a model for understanding bacterial mercury methylation. Applied and Environmental Microbiology 77:3,938-3,951, http://dx.doi.org/10.1128/AEM.02993-10.

Hammerschmidt, C.R., and K.L. Bowman. 2012. Vertical methylmercury distribution in the subtropical North Pacific. Marine Chemistry 132-133:77-82, http://dx.doi.org/ 10.1016/j.marchem.2012.02.005.

Krabbenhoft, D.P., and E.M. Sunderland. 2013. Global change and mercury. Science 341:1,457-1,458, http://dx.doi.org/ $10.1126 /$ science. 1242838 .

Mahaffey, K.R., R.P. Clickner, and R.A. Jeffries. 2009. Adult women's blood mercury concentrations vary regionally in the United States: Association with patterns of fish consumption (NHANES 1999-2004). Environmental Health Perspectives 117:47-53, http://dx.doi.org/ 10.1289/ehp.11674.

Mason, R.P., A.L. Choi, W.F. Fitzgerald, C.R. Hammerschmidt, C.H. Lamborg, A.L. Soerensen, and E.M. Sunderland. 2012. Mercury biogeochemical cycling in the ocean and policy implications. Environmental Research 119:101-117, http://dx.doi.org/ 10.1016/j.envres.2012.03.013.

Mason, R.P., and W.F. Fitzgerald. 1993. The distribution and biogeochemical cycling of mercury in the Equatorial Pacific Ocean. Deep Sea Research Part I 40:1,897-1,924, http:// dx.doi.org/10.1016/0967-0637(93)90037-4.

Parks, J.M., A. Johs, M. Podar, R. Bridou, R.A. Hurt Jr., S.D. Smith, S.J. Tomanicek, Y. Qian, S.D. Brown, C.D. Brandt, and others. 2013. The genetic basis for bacterial mercury methylation. Science 339:1,332-1,335, http:// dx.doi.org/10.1126/science.1230667.

Rajar, R., M. Cetina, M. Horvat, and D. Zagar. 2007. Mass balance of mercury in the Mediterranean Sea. Marine Chemistry 107:89-102, http://dx.doi.org/ 10.1016/j.marchem.2006.10.001.

Scheuhammer, A.M., M.W. Meyer, M.B. Sandheinrich, and M.W. Murray. 2007. Effects of environmental methylmercury on the health of wild birds, mammals, and fish. Ambio 36:12-18, http://dx.doi.org/10.1579/ 0044-7447(2007)36[12:EOEMOT]2.0.CO;2.

Selin, N.E. 2013. Global change and mercury cycling: Challenges for implementing a global mercury treaty. Environmental Toxicology and Chemistry, http://dx.doi.org/10.1002/etc.2374.

Selin, N.E., E.M. Sunderland, C.D. Knightes, and R.A. Mason. 2010. Sources of mercury exposure for US seafood consumers: Implications for policy. Environmental Health Perspectives 118:137-143, http://dx.doi.org/ 10.1289/ehp.0900811.
Streets, D.G., Q. Zhang, and Y. Wu. 2009. Projections of global mercury emissions in 2050. Environmental Science \& Technology 43:2,983-2,988, http://dx.doi.org/ 10.1021/es802474j.

Sunderland, E.M., D.P. Krabbenhoft, J.W. Moreau, S.A. Strode, and W.M. Landing. 2009.

Mercury sources, distribution, and bioavailability in the North Pacific Ocean: Insights from data and models. Global Biogeochemical Cycles 23, GB2010, http://dx.doi.org/10.1029/ 2008 GB003425.

Sunderland, E.M., and R.P. Mason. 2007. Human impacts on open ocean mercury concentrations. Global Biogeochemical Cycles 21, GB4022, http://dx.doi.org/10.1029/2006GB002876.

Sunderland, E.M., and N.E. Selin. 2013. Future trends in environmental mercury concentrations: Implications for prevention strategies. Environmental Health 12:2, http://dx.doi.org/ 10.1186/1476-069x-12-2.

Tartu, S., A. Goutte, P. Bustamante, F. Angelier, B. Moe, C. Clément-Chastel, C. Bech, G.W. Gabrielsen, J.O. Bustnes, and O. Chastel. 2013. To breed or not to breed: Endocrine response to mercury contamination by an Arctic seabird. Biology Letters 9(4), http:// dx.doi.org/10.1098/rsbl.2013.0317.

Tseng, C.-M., C.H. Lamborg, and S.-C. Hsu, 2013. A unique seasonal pattern in dissolved elemental mercury in the South China Sea, a tropical and monsoon-dominated marginal sea. Geophysical Research Letters 40:167-172, http:// dx.doi.org/10.1029/2012GL054457.

Tseng, C.M., C.S. Liu, and C. Lamborg. 2012. Seasonal changes in gaseous elemental mercury in relation to monsoon cycling over the northern South China Sea. Atmospheric Chemistry and Physics 12:7,341-7,350, http://dx.doi.org/ 10.5194/acp-12-7341-2012.

UNEP (United Nations Environment Programme). 2013. Global Mercury Assessment 2013: Sources, Emissions, Releases and Environmental Transport. UNEP Chemicals Branch, Geneva, Switzerland, $42 \mathrm{pp}$. 